\title{
Penerapan Teknik Ikonik terhadap Kemampuan Pemahaman Matematika Siswa pada Pembelajaran Matematika Pokok Bahasan Pecahan
}

\author{
Ahmad Zahid ${ }^{\text {a,1) }}$, Wati Susilawati ${ }^{1}$, Asep Jihad ${ }^{1}$ dan Iyon Maryono $^{1}$ \\ ${ }^{1}$ Prodi Pendidikan Matematika, UIN Sunan Gunung Djati Bandung, \\ J1. A.H. Nasution No. 105, Cibiru , Bandung 40614, Indonesia \\ a)E-mail: pmtk@uinsgd.ac.id
}

\begin{abstract}
Abstrak. Penelitian ini bertujuan untuk mengetahui kesuksesan siswa dalam belajar matematika yang dipengaruhi oleh cara guru menyampaikan materi pelajarannya. Seorang pengajar harus mencari dan memilih metode yang tepat untuk setiap topik yang kita berikan agar siswa berpartisipasi aktif tetapi pengajaran tetap efektif dan efisien. Kemampuan guru dalam menguasai materi dan menerapkan model pembelajaran merupakan salah satu faktor yang mempengaruhi keberhasilan guru dalam proses belajar-mengajar. Salah satu teknik yang dapat digunakan sebagai alternatif penyampaian materi adalah teknik ikonik. Teknik ikonik adalah penyampaian konsep matematika dengan perantaraan gambar yang pada akhirnya siswa menemukan sendiri konsep yang dipelajari dengan perantaraan gambar tersebut. penelitian ini dilakukan dengan tujuan untuk mengetahui kemampuan pemahaman matematik siswa, dengan pembelajaran menggunakan Teknik Ikonik. Metode yang digunakan dalam penelitian ini adalah penelitian tindakan kelas (Classroom Action Research) dengan subjek penelitian kelas VII SMP Negeri 1 Pangatikan Kabupaten Garut yang terdiri dari 21 siswa laki-laki dan 13 siswa perempuan. Adapun hasil yang diperoleh adalah (a) aktivitas guru selama proses pembelajaran selalu berpijak pada tahap-tahap teknik ikonik yang disesuai dengan indikator aktivitas guru, aktivitas belajar siswa selama proses pembelajaran dikategorikan baik,
\end{abstract}

Kata Kunci. Teknik ikonik, Pemahaman matematika

\section{Pendahuluan}

Matematika merupakan salah satu mata pelajaran yang diberikan disemua jenjang pendidikan. Hal ini dikarenakan matematika adalah ilmu dasar yang mempunyai peranan penting dalam ilmu pengetahuan dan teknologi. Menurut Ruseffendi (1991: 208).

Matematika sebagai salah satu bidang studi atau mata pelajaran yang disajikan dalam penyelenggaraan kegiatan belajar mengajar memegang peranan penting dalam pendidikan masyarakat baik sebagai objek langsung (fakta, keterampilan, konsep, prinsipil) maupun objek tak langsung (bersikap kritis, logis, tekun, mampu memecahkan masalah, dan lain-lain). Karena pentingnya bidang studi matematika, maka ditingkat sekolah dasar, sekolah menengah, dan sebagian besar perguruan tinggi, matematika diberikan minimum sebagai mata pelajaran (kuliah) umum yang harus diketahui oleh semua siswa (mahasiswa).Oleh sebab itu konsep dasar matematika yang diajarkan kepada siswa haruslah kuat dan benar. 
Proses kegiatan belajar mengajar matematika harus diatur sedemikian rupa sehingga sesuai dengan tahapan berfikir siswa. Ada baiknya jika dalam pembelajaran matematika siswa diberi kesempatan untuk memanipulasi benda -benda konkrit, membuat model, diagram, dan lainnya sebagai alat perantara untuk merumuskan dan menyajikan konsep abstrak. Penyajian konsep abstrak dalam bentuk konkrit diharapkan bisa membantu siswa agar dapat belajar matematika dengan lebih bermakna dan konsep materi yang disampaikan bisa lebih mudah dipahami.

Kesuksesan siswa dalam belajar matematika sangat dipengaruhi oleh cara guru menyampaikan materi pelajarannya. Hal ini sesuai dengan pendapat Ruseffendi (1991: 20) bahwa kita harus mencari dan memilih metode yang tepat untuk setiap topik yang kita berikan agar siswa berpartisipasi aktif tetapi pengajaran tetap efektif dan efisien. Kemampuan guru dalam menguasai materi dan menerapkan model pembelajaran merupakan salah satu faktor yang mempengaruhi keberhasilan guru dalam proses belajar-mengajar. Salah satu teknik yang dapat digunakan sebagai alternatif penyampaian materi adalah teknik ikonik.

Menurut Dlurotun (2005: 18) teknik ikonik adalah penyampaian konsep matematika dengan perantaraan gambar yang pada akhirnya siswa menemukan sendiri konsep yang dipelajari dengan perantaraan gambar tersebut. Margaret (1994: 107) menyatakan, materi yang disajikan dengan bantuan gambar ternyata mampu mengidentifikasi dengan teliti sebanyak 69\% dalam waktu 270 millisecond. Sedangkan jika materi disajikan tanpa gambar ternyata peserta mampu mengidentifikasi dengan kadar yang sama dengan waktu yang lebih lama yaitu 370 millisecond atau selisih 100 millisecond. Dari penyataan tersebut dapat disimpulkan, materi yang disampaikan dengan teknik ikonik yaitu dengan menggunakan media gambar. Tujuannya adalah untuk menjembatani/ memperjelas konsep yang masih abstrak menjadi lebih kokrit sehingga diharapkan dapat membantu mempercepat sampainya informasi atau materi kepada siswa, atau dengan kata lain siswa dapat lebih cepat memahami suatu konsep/ materi yang disampaikan oleh guru, sehingga diasumsikan melalui teknik ikonik ini kemampuan pemahaman matematika siswa dapat meningkat.

Pada penelitian ini, penulis memilih pokok bahasan Pecahan, karena dalam materi tersebut banyak konsep abstrak yang berhubungan dengan bilangan yang haarus dipahami siswa, pada pembelajaran dengan teknik ikonik ini diharapkan dapat meningkatkan pemahaman matematika siswa sehingga siswa bisa lebih mudah memahami materi yang dipelajari serta dapat menyelesaikan permasalahan yang Jurnal Analisa Vol.1 No.1 Juni 2013 :12-19 
berkaitan dengan materi tersebut berdasarkan uraian di atas, penulis berasumsi bahwa pembelajaran yang tepat untuk meningkatkan pemahaman matematika siswa pada pembelajaran matematika pokok bahasan pecahan adalah dengan pembelajaran teknik ikonik.

Oleh karena itu, peneliti merasa tertarik untuk melakukan penelitian dengan tujuan menelaah proses pembelajaran matematika dengan teknik ikonik yang diterapkan di kelas VII SMPN 1 Pangatikan pada tiap siklus sehingga dapat diketahui keaktivan siswa selama pembelajaran berlangsung, menelaah kemampuan pemahaman matematika siswa kelas VII SMPN 1 Pangatikan melalui penerapan pembelajaran teknik ikonik sehingga dapat diketahui indikator pemahaman mana yang sudah dikuasai dan belum dikuasai siswa pada tiap siklus, menelaah kemampuan pemahaman matematika siswa kelas VII SMPN 1 Pangatikan setelah siswa melalui penerapan pembelajaran teknik ikonik sehingga dapat diketahui indikator pemahaman mana yang sudah dikuasai dan belum dikuasai siswa setelah seluruh siklus dilaksanakan menelaah sikap siswa kelas VII SMPN 1 Pangatikan terhadap pembelajaran matematika dengan menggunakan teknik ikonik sehingga dapat diketahui siswa mana saja yang bersikap positif dan bersikap negatif terhadap pembelajaran ini.

\section{Metodologi Penelitian}

Penelitian ini mengambil lokasi di SMP Negeri 1 Pangatikan. Adapun yang menjadi sampel penelitian adalah siswa kelas VII. Pendekatan yang digunakan dalam penelitian ini adalah pendekatan penelitian tindakan kelas (Classroom Action Research), yang berusaha mengkaji dan merefleksi suatu model pembelajaran dengan tujuan untuk meningkatkan proses dan produk pengajaran di kelas.

Prosedur penelitian ini ada beberapa tahapan yang dilakukan, yaitu identifikasi masalah, perencanaan atau pelaksanaan tindakan, pelaksanaan tindakan, analisis dan refleksi, pelaksanaan tindakan tercapai. Instrumen yang digunakan untuk mengumpulkan data dalam penelitian ini adalah lembar observasi Observasi digunakan untuk mengamati aktivitas siswa dan aktivitas guru selama proses Kegiatan Belajar Mengajar (KBM), instrumen tes kemampuan pemahaman matematik yang digunakan berupa tes uraian yang meliputi tes formatif dan post test.

\section{Hasil dan Pembahasan}

Kemampuan Pemahaman Matematik Siswa pada Tiap Siklus melalui Penerapan Pembelajaran Dengan teknik ikonik 
Siklus I

Berdasarkan hasil perhitungan data tes pada siklus I diperoleh keterangan bahwa ketuntasan belajar siswa secara klasikal pada siklus I sebesar 85,29\% atau 29 siswa dari 34 siswa, dan daya serap siswa adalah $60,59 \%$ artinya materi bisa dilanjutkan ke materi selanjutnya. Tindak lanjut bagi siswa yang belum tuntas mengikuti pembelajaran adalah lebih ditekankan agar siswa dapat memahami soal berbentuk pemahaman matematik. Sedangkan rata-rata kemampuan pemahaman matematika siswa pada siklus I adalah $67,94 \%$ dengan kriteria penilaian cukup.

Sedangkan persentase kemampuan pemahaman matematik siswa berdasarkan indikator pemahaman dapat dilihat pada sebagai berikut.

Persentase pemahaman matematik siswa untuk menemukan masalah yaitu $91,17 \%$; merumuskan masalah yaitu 62,74\%; mengaitkan satu konsep dengan konsep lain yaitu 56,86\%; menyelesaikan operasi hitung aljabar yaitu 57,84\%; dan interpretasi gambar mengenai materi yaitu 43,13\%. Pada siklus I, masih banyak siswa yag merasa kesulitan dalam merencanakan strategi pemahaman matematik. Hal ini disebabkan siswa belum terbiasa dengan soal-soal pemahaman matematik. Selain hal tersebut, faktor yang mempengaruhi kesulitan siswa dalam merencanakan strategi pemahaman matematik yakni siswa belum bisa mengaitkan konsepkonsep yang relevan dan menunjang untuk pemahaman matematik pada materi pecahan.

Berdasarkan hasil perhitungan data tes pada siklus II diperoleh keterangan ketuntasan belajar siswa secara klasikal pada siklus II sebesar $88,24 \%$ atau 30 siswa dari 34 siswa, dan daya serap siswa adalah $64,41 \%$ artinya materi sudah bisa dilanjutkan kembali ke materi selanjutnya. Sedangkan rata-rata kemampuan pemahaman matematik siswa diperoleh sebesar 75,14\% dengan kriteria baik. Sedangkan persentase kemampuan pemahaman matematik siswa berdasarkan indikator pemahaman dapat dilihat sebagai berikut

Persentase pemahaman matematik siswa untuk menemukan masalah yaitu 96,08\%; merumuskan masalah yaitu $73,53 \%$; mengaitkan satu konsep dengan konsep lain yaitu 67,65\%; menyelesaikan operasi hitung aljabar yaitu 68,63\%; dan interpretasi gambar mengenai materi yaitu $62,75 \%$.

Dengan demikian, terlihat bahwa ada peningkatan yang signifikan dalam kemampuan pemahaman matematik dari siklus I ke siklus II, siswa sudah dapat merencanakan strategi pemahaman matematik, walaupun ada juga yang masih belum tuntas dalam menyelesaikan masalah. Hal ini disebabkan siswa mulai Jurnal Analisa Vol.1 No.1 Juni 2013 :12-19 
Penerapan Teknik Ikonik terhadap Kemampuan Pemahaman Matematika Siswa pada Pembelajaran Matematika Pokok Bahasan Pecahan

terbiasa dengan soal-soal pemahaman matematik, siswa juga sudah dapat mengaitkan konsep-konsep yang relevan dan menunjang untuk menyelesaikan masalah.

\section{Siklus III}

Berdasarkan hasil perhitungan data tes siklus III diperoleh keterangan ketuntasan belajar siswa secara klasikal sebesar $100 \%$ atau 34 siswa dari 34 siswa, sedangkan daya serap siswa adalah $77,79 \%$. Siswa yang tuntas sebanyak 34 orang dari 34 Siswa yang mengikuti tes evaluasi siklus III sehingga tidak ada siswa tidak tuntas, artinya ketuntasan siswa belajar pada siklus III sebesar 100\%.

Sedangkan rata-rata kemampuan pemahaman matematik siswa diperoleh sebesar $77,79 \%$ dengan kriteria baik. Sedangkan persentase kemampuan pemahaman matematik siswa berdasarkan indikator pemahaman pada siklus III dapat dilihat sebagai berikut.

Persentase pemahaman matematik siswa untuk menemukan masalah yaitu 97,05\%; merumuskan masalah yaitu $88,23 \%$; mengaitkan satu konsep dengan konsep lain yaitu 74,50\%; menyelesaikan operasi hitung aljabar yaitu 75,96\%; dan interpretasi gambar mengenai materi yaitu $75,49 \%$.

\subsection{Kemampuan Pemahaman Matematik Setelah Mengikuti Seluruh Siklus Melalui Pembelajaran Dengan Tenik Ikonik}

Berdasarkan hasil perhitungan data tes akhir diperoleh keterangan bahwa hasil belajar siswa pada pokok bahasan bangun ruang sisi lengkung sesuai dengan kriteria belajar tuntas yaitu diperoleh $100 \%$ siswa telah belajar tuntas secara klasikal atau 34 siswa dari 34 siswa. Hal ini menunjukan bahwa tidak ada siswa yang tidak tuntas belajar. Sedang kan daya serap $80,38 \%$ dengan rincian dapat dilihat pada Tabel 3.22. berikut.

Tabel 3.22. Ketuntasan Belajar Siswa pada Tes Akhir

\begin{tabular}{|c|c|c|}
\hline Kriteria & $\begin{array}{c}\text { Jumlah } \\
\text { Siswa }\end{array}$ & $\begin{array}{c}\text { Daya } \\
\text { Serap (\%) }\end{array}$ \\
\hline $\begin{array}{c}\text { Siswa yang } \\
\text { mengerjakan soal } \geq \\
60 \%\end{array}$ & 34 orang & \\
\hline $\begin{array}{c}\text { Siswa yang } \\
\text { mengerjakan soal } \\
<60 \%\end{array}$ & - & \\
\hline
\end{tabular}

Sedangkan rata-rata kemampuan pemahaman matematik siswa pada tes akhir adalah sebesar $78,43 \%$ dengan kriteria penilaian baik. Adapun banyaknya siswa yang memiliki kemampuan pemahaman matematik siswa sesuai dengan kriteria penilaian dapat dilihat pada Tabel 3.23. 
Tabel 3.23. Kemampuan Pemahaman

Matematik Siswa pada Tes Akhir

\begin{tabular}{|c|c|l|}
\hline $\begin{array}{c}\text { Kategori } \\
\text { Kemampuan } \\
\text { Pemahaman } \\
\text { Matematik Siswa }\end{array}$ & $\begin{array}{c}\text { Jumlah } \\
\text { Siswa }\end{array}$ & $\begin{array}{c}\text { Kriteria } \\
\text { Penilaian }\end{array}$ \\
\hline $90 \leq A<100$ & 6 & $\begin{array}{l}\text { Sangat } \\
\text { Tinggi }\end{array}$ \\
\hline $75 \leq B<90$ & 21 & Tinggi \\
\hline $55 \leq C<75$ & 7 & Cukup \\
\hline $40 \leq D<55$ & - & Rendah \\
\hline $0 \leq E<40$ & - & $\begin{array}{l}\text { Sangat } \\
\text { rendah }\end{array}$ \\
\hline
\end{tabular}

Dari tabel 3.23. dan Gambar 3.32. diperoleh informasi bahwa ada 6 orang siswa $(17,65 \%)$ mendapat nilai sangat tinggi, 21 orang $(61,76 \%)$ mendapat nilai tinggi, 7 orang $(20,59 \%)$ dan tidak seorangpun yang mendapat nilai rendah dan sangat rendah.

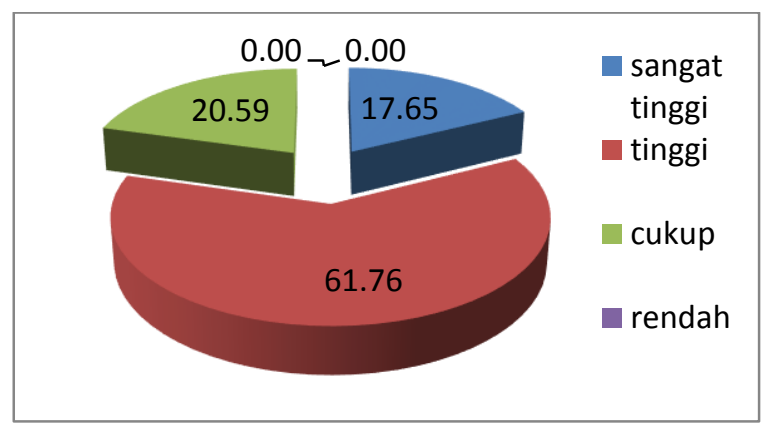

Gambar 3.32. Grafik Kemampuan

Pemahaman Matematik Siswa pada Tes akhir

Sehingga dapat disimpulkan bahwa kemampuan pemahaman matematik pada Tes Akhir dikategorikan baik. Hal ini menunjukan bahwa siswa sudah mampu mengembangkan kemampuan pemahaman matematiknya pada materi Bilangan Pecahan menggunakan pembelajaran dengan teknik ikonik.

Sedangkan persentase kemampuan pemahaman matematik siswa berdasarkan indikator pemahaman dapat dilihat pada Tabel 3.24. dan diperoleh bahwa persentase kemampuan siswa pada Tes akhir tiap indikator pemahaman adalah seperti terlihat pada Gambar 3.33.

Tabel 3.24. Persentase Kemampuan Pemahaman Matematik Berdasarkan Indikator Pemahaman pada Tes Akhir

\begin{tabular}{|l|c|c|c|c|c|c|}
\hline \multirow{2}{*}{$\begin{array}{c}\text { Indikator Pemahaman } \\
\text { Matematik }\end{array}$} & \multicolumn{5}{|c|}{ Banyak Siswa } & \multirow{2}{*}{$\begin{array}{c}\text { Persentase Kemampuan } \\
\text { Pemahaman Matematik (\%) }\end{array}$} \\
\cline { 2 - 8 } & 1 & 2 & 3 & 4 & 5 & $100 \%$ \\
\hline 1. Menemukan masalah & 34 & 34 & 34 & 34 & 34 & $99 \%$ \\
\hline 2. Merumuskan masalah & 34 & 34 & 34 & 33 & 33 & $81 \%$ \\
\hline $\begin{array}{l}\text { 3. } \\
\text { Mengaitkan satu konsep } \\
\text { dengan konsep lain }\end{array}$ & 33 & 32 & 25 & 30 & 17 & $79 \%$ \\
\hline $\begin{array}{l}\text { 4. } \begin{array}{l}\text { Menyalesaikan operasi } \\
\text { hitung aljabar }\end{array} \\
\text { 5. Interpretasi gambar } \\
\text { mengenai materi }\end{array}$ & 34 & 29 & 26 & 27 & 20 & $71 \%$ \\
\hline
\end{tabular}

Berdasarkan Tabel 3.24. persentase pemahaman matematik siswa untuk menemukan masalah yaitu $100 \%$; merumuskan masalah yaitu 99\%; mengaitkan satu konsep dengan konsep lain yaitu $81 \%$; menyelesaikan operasi hitung aljabar yaitu 79\%; dan interpretasi gambar mengenai materi yaitu $71 \%$.

Pada Gambar 3.33 diperoleh informasi bahwa rata-rata persentase kemampuan pemahaman matematik siswa nilai rata-rata post test sebesar 78,43\% dengan kriteria penilaian tinggi

Jurnal Analisa Vol.1 No.1 Juni 2013 :12-19 
Penerapan Teknik Ikonik terhadap Kemampuan Pemahaman Matematika Siswa pada Pembelajaran Matematika Pokok

Bahasan Pecahan

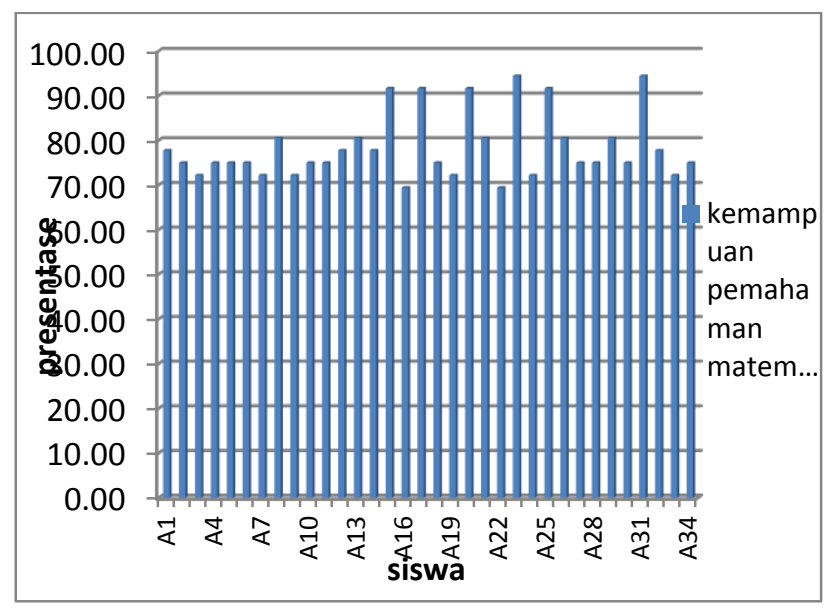

Gambar 3.33. Grafik Persentase Kemampuan

Siswa dalam Memahami Masalah pada Tes

\section{Akhir}

Secara keseluruhan perkembangan hasil belajar siswa selama pembelajaran dengan menggunakan teknik ikonik dari Siklus I sampai Siklus III hingga tes akhir, dapat dilihat rinciannya pada Tabel 3.25 berikut:

Tabel 3.25. Tingkat Ketuntasan Belajar Siswa pada Materi Bilangan Pecahan

\begin{tabular}{|c|c|c|c|}
\hline $\begin{array}{c}\text { Tes } \\
\text { Evaluasi }\end{array}$ & $\begin{array}{c}\text { Ketuntasan } \\
\text { Belajar (\%) }\end{array}$ & $\begin{array}{c}\text { Daya } \\
\text { Serap } \\
(\%)\end{array}$ & $\begin{array}{c}\text { Kriteria } \\
\text { Ketuntasan }\end{array}$ \\
\hline Siklus I & $85,29 \%$ & $60,59 \%$ & Baik \\
\hline $\begin{array}{c}\text { Siklus II } \\
\text { Siklus } \\
\text { III }\end{array}$ & $100 \%$ & $77,79 \%$ & Baik \\
\hline $\begin{array}{c}\text { Tes } \\
\text { Akhir }\end{array}$ & $100 \%$ & $78,43 \%$ & Baik \\
\hline
\end{tabular}

Berdasarkan Tabel 3.25. diperoleh informasi persentase Tingkat kesukaran belajar siswa. Untuk ketuntasan belajar dari siklus I ke siklus Jurnal Analisa Vol.1 No.1 Juni $2013: 12-19$
II mengalami peningkatan sebesar $2,95 \%$; dari siklus II ke siklus III mengalami peningkatan sebesar $11,76 \%$; sedangkan rata-rata persentase ketuntasan belajar siswa pada tes akhir sebesar $100 \%$ dengan kriteria penilaian sangat baik. Adapun untuk daya serap dari siklus I ke siklus II mengalami peningkatan sebesar 3,82\%; dari siklus II ke siklus III mengalami peningkatan sebesar 13,38\%; sedangkan persentase daya serap pada tes akhir sebesar 78,43\% dengan kriteria penilaian baik.

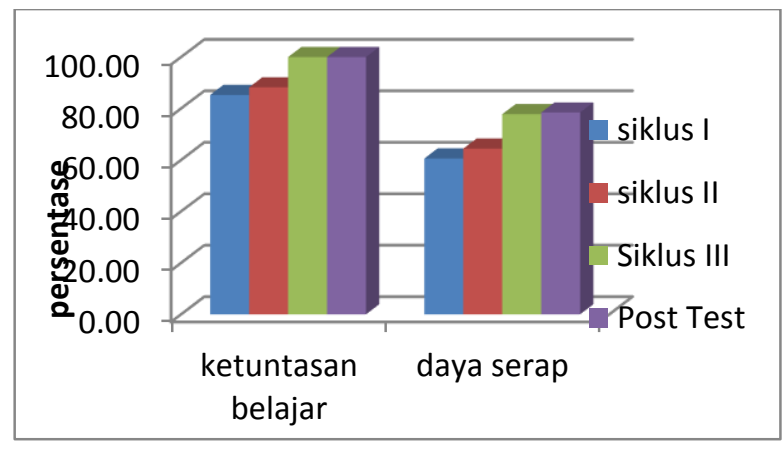

Gambar 3.34. Grafik Tingkat Ketuntasan

Belajar dan Daya Serap Siswa pada Materi Bilangan Pecahan

Seperti halnya ketuntasan belajar siswa, kemampuan pemahaman matematik siswa pada tiap siklusnya setelah pembelajaran dengan menggunakan teknik ikonik juga mengalami peningkatan. Hal tersebut dapat terlihat dari peningkatan rata-rata persentase kemampuan pemahaman matematik siswa pada tiap siklus seperti terlihat pada Tabel 3.26. berikut

Tabel.3.26. Rata-rata Kemampuan Pemahaman Matematik Siswa pada Tiap Siklus 


\begin{tabular}{|c|c|c|}
\hline Tes & $\begin{array}{c}\text { Rata-rata Persetase } \\
\text { Kemampuan }\end{array}$ & \\
Evaluasi & $\begin{array}{c}\text { Pemahaman } \\
\text { Matematik Siswa }\end{array}$ & \\
\hline Siklus I & $67,94 \%$ & Cukup \\
\hline Siklus II & $70,29 \%$ & Baik \\
\hline Siklus III & $77,79 \%$ & Baik \\
\hline Tes Akhir & $78,43 \%$ & Baik \\
\hline
\end{tabular}

Dari tabel 3.26 diketahui rata-rata persentase kemampuan pemahaman matematik siswa yang terendah ada pada siklus I yaitu $67,94 \%$ sedangkan yang tertinggi ada pada post test yaitu 78,43\%. Namun untuk melihat kemampuan pemahaman siswa secara keseluruhan terlihat pada gambar 3.35 sebagai berikut:

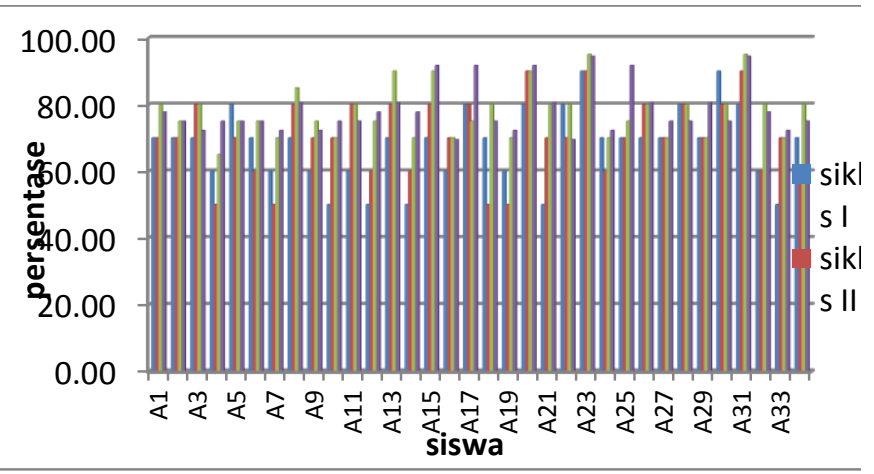

Gambar 3.35. Grafik Perkembangan Rata-rata

Kemampuan Pemahaman Matematik Siswa

Pada Gambar 3.35. terlihat bahwa kemampuan pemahaman matematik siswa meningkat pada siklus I ke siklus II dan dari siklus II ke siklus III, peningkatan ini disebabkan motivasi siswa untuk mempelajari materi meningkat, karena mereka menghadapi materi yang penuh dengan cerita yang sering mereka hadapi dalam kehidupan sehari-hari, tentu saja dengan penyajian materi yang menyenangkan oleh guru, dan adanya pembelajaran yang menuntut siswa untuk berulang. sedangkan persentase kemampuan pemahaman matematik siswa pada tes akhir sebesar $78,43 \%$ dengan kriteria penilaian baik.

\section{Simpulan dan Saran (12 pt, bolt)}

Berdasarkan analisis data hasil penelitian tentang penerapan teknik ikonik terhadap kemampuan pemahaman matematika siswa pada pembelajaran matematika pokok bahasan pecahan, maka di dapat kesimpulannya yaitu dari hasil analisis lembar observasi menggambarkan aktivitas siswa dalam pembelajaran matematika dengan menggunakan teknik ikonik secara keseluruhan termasuk kategori baik, hal ini ditunjukkan bahwa siswa sudah konsentrasi mengikuti kegiatan pembelajaran. Sedangkan aktivitas guru selama proses pembelajaran selalu berpijak pada tahap-tahap pembelajaran yang telah direncanakan, yaitu sesuai dengan indikator-indikator aktivitas guru.

Hasil observasi juga ditemukan bahwa peranan guru sebagai fasilitator dalam pembelajaran yakni membimbing dan mengarahkan serta memotivasi siswa dalam belajar, kemampuan pemahaman matematik siswa pada tiap siklus melalui pembelajaran dengan teknik ikonik Jurnal Analisa Vol.1 No.1 Juni 2013 :12-19 
Penerapan Teknik Ikonik terhadap Kemampuan Pemahaman Matematika Siswa pada Pembelajaran Matematika Pokok

Bahasan Pecahan

tergolong kriteria baik. Hal ini terlihat dari ratarata persentase kemampuan pemahaman matematik siswa pada siklus I sebesar $67,94 \%$ dengan kriteria cukup, siklus II sebesar 70,29\% dengan kriteria baik, siklus III sebesar 77,79\% dengan kriteria baik, berdasarkan hasil analisis tes seluruh siklus setelah diterapkannya pembelajaran dengan teknik ikonik, maka diperoleh rata-rata persentase kemampuan pemahaman matematik siswa pada tiap siklusnya mengalami peningkatan. Untuk ketuntasan belajar dari siklus I ke siklus II mengalami peningkatan sebesar 2,95\%; dari siklus II ke siklus III mengalami peningkatan sebesar 11,76\%; sedangkan rata-rata persentase ketuntasan belajar siswa pada tes akhir sebesar $100 \%$ dengan kriteria penilaian sangat baik.

Adapun untuk daya serap dari siklus I ke siklus II mengalami peningkatan sebesar 3,82\%; dari siklus II ke siklus III mengalami peningkatan sebesar 13,38\%; sedangkan persentase daya serap pada tes akhir sebesar $78,43 \%$ dengan kriteria penilaian baik, berdasarkan hasil analisis data skala sikap, diperoleh bahwa tanggapan siswa terhadap pembelajaran menggunakan teknik ikonik cukup baik. Hal ini terlihat dari rata-rata skor sikap siswa terhadap pembelajaran matematika dengan teknik ikonik menunjukkan skor sikap siswa yaitu 2,31 dan sikap netral 1,95. Skor sikap siswa terhadap tes yang diberikan guna menunutut pemahaman matematik siswa yaitu 2,94 dan sikap netral Jurnal Analisa Vol.1 No.1 Juni 2013 :12-19
2,43. Hal tersebut menunjukkan bahwa siswa memiliki sikap positif terhadap pembelajaran menggunakan teknik ikonik.

\section{Daftar Pustaka (12 pt, bolt)}

Ruseffendi. (1991). Pengantar Kepada Membantu Guru Mengembangkan Kompetensinya dalam Pengajaran Matematika untuk Meningkatkan CBSA. Bandung : Tarsito.

Ruseffendi. (1991). Penilaian Pendidikan dan Hasil Belajar Siswa Khususnya dalam Pengajaran Matematika Untuk Guru dan Calon Guru. (Diktat).

Nurjamilah, Rini.(2008). Penerapan Model Pembelajaran Pemandu Awal (Advance Organizer) untuk Meningkatkan Kemampuan Pemahaman Matematik Siswa. (Skipsi). UIN Bandung : Tidak Dipublikasikan.

Nurlaela, Iis.(2006). Pengaruh Pembelajaran Matematika Dengan Teknik Ikonik Pada Pokok Bahasan Aritmetika Sosial Terhadap Kemampuan Pemecahan Masalah Matematika (Penelitian Eksperimen di Kelas VII MTs. Persatuan Islam 3 Pameungpeuk). (Skipsi). UIN Bandung : Tidak Dipublikasikan. 